\title{
A Case of Cytomegalovirus (CMV) Vasculitis Presenting as Deep Venous Thrombosis with Pulmonary Embolism (DVT/PE) Managed with Catheter Directed Thrombolysis
}

\author{
Srilekha Sridhara ${ }^{1 *}$, Juel Chowdhury ${ }^{2}$ and Neil A Ettinger ${ }^{3}$ \\ ${ }^{1}$ Department of Hospital Medicine, Banner Baywood Medical Center, Mesa, USA \\ ${ }^{2}$ Department of Cancer Genetics, Oncomarks Research, Chicago, IL, USA \\ ${ }^{3}$ Department of Pulmonary and Critical Care Medicine, Cardiopulmonary associates of St. Luke's Hospital, St. Louis, USA
}

*Corresponding author: Srilekha Sridhara, Department of Hospital Medicine, Banner Baywood Medical Center, Mesa, USA, E-mail: srilekhasrid@gmail.com

Received: 22 Feb, 2018 | Accepted: 08 Apr, 2018 | Published: 13 Apr, 2018

Citation: Sridhara S, Chowdhury J, Ettinger AN (2018) A Case of Cytomegalovirus (CMV) Vasculitis Presenting as Deep Venous Thrombosis with Pulmonary Embolism (DVT/PE) Managed with Catheter Directed Thrombolysis. J Network Med Target Ther 1(2): dx.doi.org/10.16966/2577-1906.109

Copyright: (c) 2018 Sridhara S, et al. This is an open-access article distributed under the terms of the Creative Commons Attribution License, which permits unrestricted use, distribution, and reproduction in any medium, provided the original author and source are credited.

\begin{abstract}
Cytomegalovirus related serious complications in immunocompetent patients more frequently affect gastrointestinal tract causing colitis and central nervous system causing meningitis, encephalitis and transverse myelitis. Cytomegalovirus related thrombotic events are seen more commonly in immunocompromised patients. We describe a case of a 32-year-old healthy Caucasian male presenting with an acute febrile illness secondary to Cytomegalovirus with deep venous thrombosis and pulmonary embolism who was managed with antiviral therapy, anticoagulation and catheter directed thrombolysis.
\end{abstract}

Keywords: Cytomegalovirus; Deep venous thrombosis; Pulmonary embolism; Catheter directed thrombolysis

\section{Case report}

32-year-old healthy Caucasian male presented to the clinic after two weeks of a persistent febrile illness with 4 days of exertional dyspnea and left lower extremity swelling and pain. Patient also reported being confined to bed for the last 5 days prior to presentation. Physical examination revealed temperature of $39{ }^{\circ} \mathrm{C}$, increased left calf diameter with tenderness and positive Homan's sign. Deep venous thrombosis (DVT) of left lower extremity with pulmonary embolism (PE) was suspected and lower extremity venous doppler revealed acute extensive DVT in the left femoral, popliteal, gastrocnemius and calf veins. A contrast computed tomography chest scan using PE protocol was suggestive of bilateral pulmonary emboli. Anticoagulation with heparin and coumadin was started simultaneously. The fevers were initially thought to be secondary to thromboembolism but did not abate although patient was on heparin infusion and further evaluation showed atypical lymphocytosis and viral serology for Epstein-Barr virus, Cytomegalovirus and Herpes virus was performed. This revealed evidence of acute Cytomegalovirus (CMV) infection with elevated immunoglobulin M (IGM) of $>5.0$ and positive polymerase chain reaction (PCR) copies at 5,279 copies/mL. Treatment with ganciclovir for one week resolved his fevers and CMV PCR later became undetectable. Lower extremity pain and swelling improved and the patient was discharged on coumadin.

He was followed as an outpatient but he did not experience total resolution of lower extremity symptoms. Venous doppler of left lower extremity showed persistent venous thrombi and he received two sessions of intravascular catheter directed thrombolysis with tissue plasminogen activator, mechanical thrombectomy followed by low molecular heparin therapy (with enoxaparin) and coumadin was discontinued. (Figure 1) shows the venogram of left lower extremity before catheter directed thrombolysis and (Figure 2) shows venogram after catheter directed thrombolysis with improved venous patency.

On enoxaparin therapy, he experienced complete resolution of symptoms and was able to restart coumadin. Thrombophilia work up before initiation of anticoagulants showed presence of for lupus anticoagulant, but the repeat testing did not show this. Currently patient is maintained on aspirin and lower extremity compression stockings with no further recurrences of DVT. 


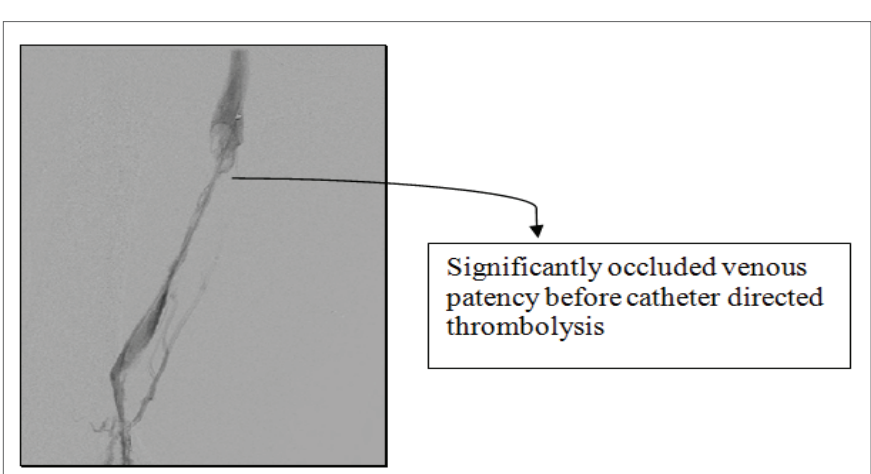

Figure 1: Venogram of left lower extremity before catheter directed thrombolysis.

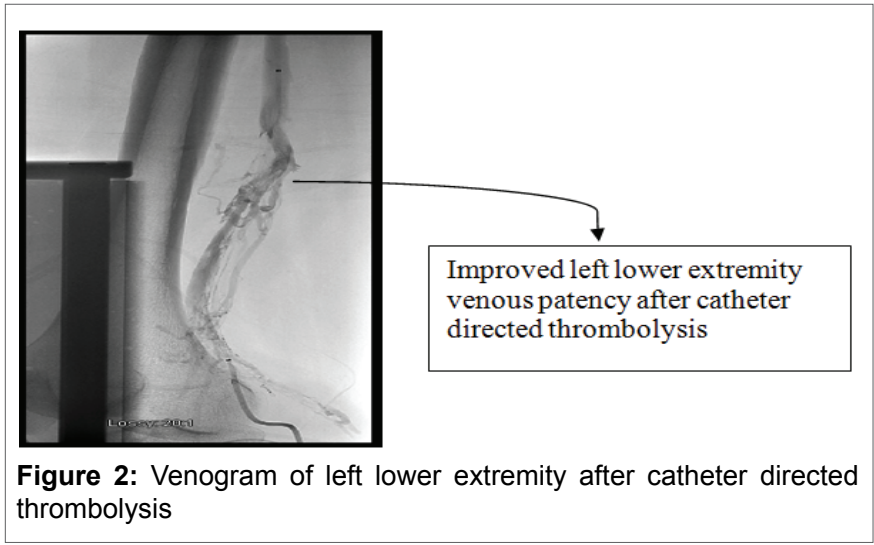

\section{Discussion}

CMV related thrombotic events are rare in immunocompetent patients and have been reported in portal, femoropopliteal and pulmonary vasculature. Patient characteristics associated with CMV thromboses are history of diabetes mellitus, immobility, use of oral contraceptive pills [1-3], presence of antiphospholipid antibodies [1], increased factor VIII level [2], previous DVT [2], presence of factor V Leiden mutation [1-3]. Plausible mechanisms for CMV vasculitis were transient increased expression of antiphospholipid antibodies, Factor VIII, transforming growth factor beta and platelet derived growth factor beta. Vascular cell wall proliferation and over expression of tissue factor, Factors VIII, $\mathrm{X}$ have also been hypothesized. Table 1 describes the various mechanisms of CMV mediated thrombosis as reported in literature.

Case reports describing PE, splenic infarcts [8], mesenteric vein thrombosis [9], jugular vein thrombosis [10], portal vein thrombosis [11] are described. Management options were systemic thrombolysis [8], local thrombolysis [9], anticoagulation $[10,11]$. Based on literature review of CMV thrombosis and management, we have compiled (Table 2).

To our knowledge, this is the first case of CMV associated thrombosis with DVT/PE managed with catheter directed thrombolysis after 3 weeks of presentation. Usual indication for catheter directed thrombolysis is within 2 weeks of onset of DVT. In our patient, this was done 3 weeks after presentation
Table 1: CMV Mediated Thrombosis Mechanisms

\begin{tabular}{|l|l|}
\multicolumn{1}{|c|}{ Authors } & \multicolumn{1}{|c|}{$\begin{array}{c}\text { Factor expression for thrombosis } \\
\text { Mechanism }\end{array}$} \\
\hline V D Mieras et al; [4] & $\begin{array}{l}\text { Tissue factor mediated Extrinsic pathway } \\
\text { activation }\end{array}$ \\
\hline Zhou et al; [5] & $\begin{array}{l}\text { Platelet derived growth factor Smooth muscle } \\
\text { migration receptor alpha }\end{array}$ \\
\hline MichelsonS et al; [6] & $\begin{array}{l}\text { Transforming growth factor beta -1 CMV } \\
\text { replication }\end{array}$ \\
\hline Westphal M et al., [7] & $\begin{array}{l}\text { Vascular cell adhesion molecule Vascular cell } \\
\text { wall proliferation }\end{array}$ \\
\hline
\end{tabular}

Table 2: Case Reports Describing CMV Thrombosis and Management

\begin{tabular}{|c|c|}
\hline Case Description & $\begin{array}{c}\text { Pertinent } \\
\text { Laboratory Data }\end{array}$ \\
\hline $\begin{array}{l}\text { 1. 30-year-old womanwas managed for- } \\
\text { CMV associated splenic infarction and } \\
\text { massive pulmonary embolism. } \\
\text { Thrombolysis discontinued due to bleeding } \\
\text { from } \\
\text { Peripheral intravenous lines. Later treated with } \\
\text { anticoagulation with heparin and Coumadin [8]. }\end{array}$ & $\begin{array}{l}\text { Transient anti- } \\
\text { cardiolipin } \\
\text { antibody } \\
\text { elevation } \\
\text { Persistent } \\
\text { anti beta-2 } \\
\text { glycoprotein } 1 \\
\text { antibodies }\end{array}$ \\
\hline $\begin{array}{l}\text { 2. 56-year-old malewas managed for- } \\
\text { CMV associated superior mesenteric vein } \\
\text { thrombosis. } \\
\text { Failure of systemic thrombolysis and heparin } \\
\text { infusion, later was given local thrombolysis } \\
\text { into } \\
\text { superior mesenteric artery, followed by oral } \\
\text { anticoagulation for } 6 \text { months [9]. }\end{array}$ & $\begin{array}{l}\text { Elevation of } \\
\text { anti-cardiolipin } \\
\text { antibodies } \\
\text { and lupus } \\
\text { anticoagulant }\end{array}$ \\
\hline $\begin{array}{l}\text { 3. 32-year-old female was managed for- } \\
\text { CMV associated phlebitis, pulmonary } \\
\text { embolism and left internal jugular vein } \\
\text { thrombosis. Was treated with low molecular } \\
\text { weight heparin and Coumadin [10]. }\end{array}$ & $\begin{array}{l}\text { Serology with } \\
\text { CMV PP } 65 \\
\text { antigenemia, } \\
\text { CMV blood } \\
\text { culture of } \\
\text { buffy coat, } \\
\text { Heterozygous- } \\
\text { Factor V mutation }\end{array}$ \\
\hline $\begin{array}{l}\text { 4 .31-year-old female, smoker, on oral } \\
\text { contraceptive pills was managed for- } \\
\text { CMV associated partial portal vein } \\
\text { thrombosis, treated with anticoagulation [11]. }\end{array}$ & $\begin{array}{l}\text { CMV PCR } \\
\text { positive for } \\
\text { viremia was } \\
\text { noted }\end{array}$ \\
\hline
\end{tabular}

secondary to ongoing CMV pathogenesis with continued thrombosis in spite of anticoagulation. By pursuing catheter directed thrombolysis and continuing anticoagulation we were able to achieve symptom relief and have improved patient outcomes.

\section{Conclusion}

This case emphasizes the importance of looking for infectious etiologies for vasculitis contributing to DVT/ $\mathrm{PE}$ in immunocompetent patients presenting with febrile illness. Treatment of the underlying CMV infection and proper appraisal of pathogenesis of thromboses might help in guiding management decisions. Considering catheter directed thrombolysis for recurrent thromboses will help improve clinical symptoms and achieve better patient outcomes. Frequent follow up for clot resolution and prevention of post thrombotic syndrome is essential. 


\section{Conflicts of interest}

There are no conflicts of interest.

\section{Patient consent}

Patient's consent was obtained for journal publication.

\section{References}

1. Justo D, Finn T, Atzmony L, Guy N, Steinvil A (2011) Thrombosis associated with acute cytomegalovirus infection: A metaanalysis. Eur J Intern Med 22: 195-199.

2. Tichelaar VY, Sprenger HG, Mäkelburg ABU, Niesters BGM, KluinNelemans HC, et al. (2011). Active cytomegalovirus infection in patients with acute venous thrombosis: a case-control study. Am J Hematol 86: 510-512.

3. Atzmony L, Grosfeld A, Saar N, Justo D (2010) Inherited and acquired predispositions for thrombosis in immunocompetent patients with cytomegalovirus- associated thrombosis. Eur J Intern Med 21: 2-5.

4. van Dam-Mieras MC, Muller AD, van Hinsbergh VW, Mullers WJ, Bomans PH, et al. (1992) The procoagulant response of cytomegalovirus infected endothelial cells. Thromb Haemost 68: 364-370.

5. Kabanova A, Marcandalli J, Zhou T, Bianchi S, Baxa U, et al. (2016) Platelet-derived growth factor- $\alpha$ receptor is the cellular receptor for human cytomegalovirus gHgLgO trimer. Nat Microbiol 1: 16082.
6. Michelson S, Alcami J, Kim SJ, Danielpour D, Bachelerie F, et al (1994) Human cytomegalovirus infection induces transcription and secretion of transforming growth factor beta 1. J Virol 68: 5730-5737.

7. Westphal M, Lautenschlager I, Backhaus C, Loginov R, Kundt G, et al. (2006) Cytomegalovirus and proliferative signals in the vascular wall of CABG patients. Thorac Cardiovasc Surg 54: 219-226.

8. Poon ML, Tang JW, Chee YL (2012) Case Report: CytomegalovirusInduced Thrombosis in an Immunocompetent Patient. J Med Virol 84: 116-118.

9. Van Moerkercke W, Pauwelyn K, Brugman E, Verhamme M (2009) Cytomegalovirus-associated superior mesenteric vein thrombosis treated with systemic and in-situ thrombolysis. Eur J Gastroenterol Hepatol 21: 587-592.

10. Abgueguen P, Delbos V, Chennebault JM, Payan C, Pichard E (2003) Vascular Thrombosis and Acute Cytomegalovirus Infection in Immunocompetent Patients: Report of 2 Cases and Literature Review. Clin Infect Dis 36: 134-139.

11. Estival JL, Debourdeau P, Zammit C, Teixeira L, Guérard S, Colle B (2001) Spontaneous portal vein thrombosis associated with acute cytomegalovirus infection in an immunocompetent patient. Presse Med 30: 1876-1878. 